\title{
CONFLICT AND CONFLICT MANAGEMENT IN NIGERIAN UNIVERSITIES: A STUDY OF ROGER MAKANJUOLA'S 'WATER MUST FLOW UPHILL: ADVENTURES IN UNIVERSITY ADMINISTRATION’
}

\author{
K. A. Bakare \\ Deputy Registrar, \\ Obafemi Awolowo University, \\ Ile-Ife, Nigeria
}

\begin{abstract}
:
Conflict is a fact of life. The tongue-and-mouth dialectical discourse in Yoruba proverb typifies the inevitability of dissonance and dissension in a complex social system. Socialization, therefore, whether primary, anticipatory, professional or re-socialization, is fraught with conflicts. Ideological contestation over socioeconomic policies forms the basis of conflicts in the university in Nigeria. Conflicts in Nigeria has its antecedents in the colonial era (Bakare, K.A., 2021). A scenario of contest is ever constant, when the leadership is perceived as a comprador capitalist by the followership. At the basis of every trade union in Nigeria is the determination to rebuff exploitative capitalism. The university with its demographics, proxemics and vast municipal requirements is prone to conflict in an expansive proportion. Having noted that conflict is a constant variable, it is important to zero down on its management, its mismanagement and its resolution, situating it within a concrete context. In our attempt to show the nuances of conflict in the university estate, we have opted to study realistic episodes of conflicts as captured by a former Chief Medical Director cum Vice-Chancellor of a foremost university in Nigeria. The book, 'Water must flow uphill' is an experiential rendition of the abecedarian precepts of leadership and management in two complex organizations. It is a fluid and transparent expose on 'how to' and 'how not to' manage conflicts in large organizations. Its turbulence, wisdom, severity and chicaneries exemplify the coarse nature of leadership in Nigerian universities and allied estates, as experienced by a viciously honest personality. Militancy, mismanagement, honesty of purpose, leadership botherations; all form the themes of a book which stands out in its attempt to capture unbiased facts. It is a definitive statement on the need for moral and ethical re-alignment in the Nigerian workspace, and the larger society.
\end{abstract}

${ }^{i}$ Correspondence: email tunjibakare@yahoo.com 
Keywords: conflict, dissonance, socialization, exploitative capitalism, proxemics, university estate

\section{Introduction}

Karl Marx purported that conflict is an inevitable part of life because of a 'never-ending competition for finite resources.'

In essence, conflict and conflict management is a continuum in human experience that leaves the human society constantly in a state of funk as a result of the never-ending struggle for acquisition of wealth between the rich and the poor. As a result of this natural instinct towards conflict, the human society, in its struggle to close the wealth gap, is embroiled in crises of inequality and natural disparity. Marxism, therefore, acquires its relevance from class conflict and the struggle to achieve parity. Historical materialism maintained that religion, morality, social structures and other forms of knowledge are rooted in economics and that the proletariat needed to be stirred to action against '...the lords of the sword, of the soil, and of capital.' (Karl Marx, p.37)

In 'traditional' scope, conflict in an organization is condemned as destructive and counter-productive. In 'modern' interpretation, conflict is a neuter, or positive, and could actually serve to propel and galvanize the organization to greater heights (Kirchoff and Adams, 1982). Universities in Nigeria have become theatres of contest between management and students, management and staff, government and students as well as government and staff. Reasons adduced for these incessant disputes and cessation of services include unhonored agreements, i.e. when government reneges on a freely signed agreement between its agents and the workforce, high-handedness of the comprador management, skewed perceptions of the unions in the universities, inadequate funding of the education sector, non-payment of allowances, and sheer sensationalism by union officials to appear relevant. In all, conflicts in Nigerian universities are mostly avoidable, especially those involving government and the workforce, as most agitations from them are caused by government backtracking from promises made. A culture of distrust between government and the workforce has gradually been nurtured as a result of broken promises and non-committal policies. Another strand fast gaining notoriety is the conflict between the university communities and the host communities, as a result of quest for land mass, interpersonal misunderstanding or other forms of aggrandizement. A plethora of benefits of education as a developmental phenomenon is being jeopardized in traditional communities where the town-gown initiatives are either nonexistent or have paled into insignificance.

The case book, 'Water must flow uphill' is a gripping account of conflict in a university and its ancillary complex. It is a dramatization of the crippling and excruciating challenges the Nigerian university system is passing through in the wave of grueling apathy of the government-owner and the stakeholders in the university enterprise. It is also a story of doggedness and sacrifice in the midst of chaos and unreason. In the process, great strides were made, while monumental mistakes were 
committed. It is a perfect snap of conflicts and crises that have afflicted the modern-day universities in our clime and a perfect rendition of the account of one man's struggle to reconceptualize the Nigerian university system.

\section{Justification}

\subsection{Background of Study}

The attempts to rework the workspace culture in Nigerian universities have been the bane of many Chief Executives. The workspace is skewed, courtesy of inappropriate practice, paucity of funds, poverty of ideas and quasi-intellectualism. It has become almost impossible to keep abreast of positive developments and assert gold standards. The value-matrices where excellence is celebrated had given way to mammonism and cyber-crime culture. In spite of this, products of our universities go out of the country to perform creditably. Obviously, structural defects, cohabiting with the systemic devaluation in the larger society have almost brought the education sector to its knees, fomenting wealth-gap induced and other forms of conflict in our universities.

\subsection{Review of Literature}

Conflict is a major factor in human interaction that cannot be avoided. Some scholars like Posigha and Oghuvwu (2009) and others posited that conflict is infinitely negative and destructive, while scholars like Bercovitch (2011), and Fatile and Adejuwon (2011), held that conflict could be progressive, innovative, creative, and could serve to activate efficiency in an organization. Olaleye and Arogundade (2013) noted the dysfunctional nature of conflict but did not rule out its propensity for propulsion. Since conflict is a constant denominator in every human society, what matters is the effective and constructive management of conflict for industrial stability (Bloisi, 2007).

\section{Methodology}

The design used in this work is descriptive. It is a critique and evaluation of the meaning and significance of conflict situations compared and juxtaposed with findings from prior researched publications and textbooks, validating the belief that conflicts could be managed effectively, and that mistakes learnt during conflicts should serve to prevent future dystopian situations and avoid managerial pitfalls. Secondary sources of data collection remain the Internet, researched publications and relevant textbooks.

\section{Synopsis}

The world of work in HR discourse is eclectic. Since administration is 'a thinking process' and management is 'a doing process' (Tunde Monehin, 2016, p.10), the nexus between the two concepts is leadership. Our case study is a dramatization of the engagements of a 
tyro with administration/management, and how he was able to use motivation, as the ylem for success.

The title, 'Water must flow uphill' is a gravitational aberration, symbolically employed to show the amount of force required to 'push' water uphill. It is an 'againstthe-gale' rendition of 'rough-and-ready' situation leaders of complex organizations like the university face in Nigeria. The story is in two major phases; the experiences of the principal as chief executive at Ife Teaching Hospital Complex (later OAUTHC) in acting and substantive capacities as Chief Medical Director, and in Obafemi Awolowo University, Ile-Ife, Nigeria, also in acting and substantive capacities as Vice-Chancellor. In both places, stakeholders demonstrated incompatible goals, putting to play, internal and external forces that caused administrative inefficiencies (Ibukun 1997), engendering intrapersonal, interpersonal, intragroup and intergroup conflicts (Olaleye and Arogundade).

Roger Makanjuola was appointed as Acting Chief Medical Director and remained in this position for about ten months, when he ceded the post to another appointee in 1985. Despite sterling performance, he was not confirmed in substantive capacity mainly because he refused to lobby. In Nigeria, lobbying is a tacit sine qua non for all appointments. Appointments are seen, not in terms of service, but in terms of opportunities. Subsequently, he was made the Chief Medical Director in 1989 to 1997. In ten months, he was able to streamline the activities in the hospital complex, and most importantly, got his first baptism into administration. He learnt early in the task that:

"The things that make a good hospital are not an array of sophisticated and expensive equipment, but much more basic things like cleanliness, water and power supply, availability of drugs... and prompt attention to patients, particularly in emergencies...For all these, you need a fulfilled and motivated workforce. (p.6)

Coming to administration as a tabula rasa, the new CMD made motivation of the workforce his centerpiece. He promoted stagnated staff and made promotion performance-based (p. 20-22). He catered for the welfare of staff, and carved a populist, anti-corruption niche around his leadership (pp.28; 111).

One notable observation he made was the Decree no. 74 of 1979 which stipulated the appointment of Deans and Provosts as Chief Medical Directors (part-time) vis-à-vis Decree no. 10 of 1985, which revised the former to appoint CMDs in full-time capacities. He questioned the rationale behind appointing CMDs on a part-time basis, i.e. making Deans and Provosts who already had their hands full with College assignments CMDs. He also questioned the brilliance in entrusting medical practitioners with municipal responsibilities like provisions of power, water, medical items, supervising projects and other purely administrative tasks which obviously prevented them from operating strictly along the medical line. Hence, to him, appointing medical practitioners as CMDs is inappropriate: 
CONFLICT AND CONFLICT MANAGEMENT IN NIGERIAN UNIVERSITIES: A STUDY OF ROGER MAKANJUOLA'S 'WATER MUST FLOW UPHILL: ADVENTURES IN UNIVERSITY ADMINISTRATION'

"When I was CMD, much of the work consisted of ensuring the supply of water, electricity, maintenance of facilities... Why should medical professionals spend so much of their time on such matters...? To put it bluntly, what is our business looking after the cleaning of the hospital when we should be in the operating theatre? Most importantly, doctors and dentists do not have expertise in management. Their medical training does not include this discipline. (p. 72)

He learnt early enough the foundational attribute of administration; the need to motivate the workforce, since management is about "...getting things done through other people." (Adepoju Adeleke, 2001. p.13)

He built a motivated workforce by, first, de-escalating the hostile disposition of the system towards them when he promoted a large number of them whose promotions were pegged for many years, and secondly, by selling to them his values of honour, honesty and hard work. With this disposition, he navigated administrative difficulties even without a pre-designed plan. Another attribute that helped him deliver effectively was the image of transformational leadership which he sold to the workers. He always took charge when it mattered most and never ran away from challenges. Copious examples abound during his stints at the hospital and in the University, i.e. when he confronted marauding armed bandits in the middle of the night at the medical hostel, or when he severally confronted students' mob in aversion to several advice, just to affirm that brigandage would not be condoned or compensated.

At the hospital, he addressed himself to solving age-long municipal problems and engaged the Management Board in blue-sky projects. He abhorred bigmanism and defended the led in many instances. He gave the medical profession a human face by reinforcing and reaffirming the 'primum non nocere' clauses of the Hippocratic Oath, ensuring emergency treatment for patients even without insisting on payments first, and instituting welfare funds (i.e. the Oninure welfare fund) to provide for medical needs for indigent patients. His 'Emergency Pack Revolving Fund' provided drugs and materials required for emergency operations in labour wards. He successfully reconceptualized hospital care ethos from disease-centered to person-centered ethos.

In the University both as Acting and substantive Vice-Chancellor, Roger, made measurable achievements, albeit with entropic conflicts, which reached an unprecedented height during his tenure. Having been ushered in in 1999 after cult attack which led to the death of five young students, the principal was once again, thrusted upon management and administration at the highest level. He built on the previous experience from the hospital setup. He was able to defuse conflicts, though making some monumental mistakes in the process. He admitted that: "With hindsights, I accept that many of these cases could have been handled better by me." (p.40)

According to T.O. Adeyemi and S.O. Ademilua (2012), conflict refers to opposition, disagreement, and all forms of friction expressed through arguments, protests, demonstration and aggression. The book is replete with all these variants, but most importantly, it shows that mishandling of conflicts both by the management class 
and the aggressors make conflicts destructive rather than productive (Adebayo, 2007). The commingling of the interpersonal, intrapersonal, intragroup and intragroup variants makes our universities stretched theatres of contest, thus hindering advancement and productivity. Conflicts in the book could be categorized into human, industrial and communal; but our major concern shall be on the management of the industriallyinduced conflicts.

\subsection{Industrial Crises at OAUTHC}

In 1985, the Nigerian Medical Association (NMA) embarked on a national strike over the request to force the Federal Military Government to upgrade hospital facilities across the country. Led by the late Professor Beko Ransome-Kuti, the action confronted the military government headlong, but was subdued after some weeks and doctors were sacked and asked to re-apply. It got messier when reconnoiter teams were dispatched to hospitals to ascertain that the directive of government that doctors should be sacked and that "no work, no pay clause be evoked were being carried out by CMDs. Professor Makanjuola handled the matter cautiously as though he did not lay off any medical professional claiming that they carry on their services despite the industrial action, he got lucky because the team relied heavily on his report and could not travel down to verify his claims due to exigencies. After this followed a number of other actions at the national level which were effectively managed and condoned locally courtesy of his camaraderie with staff. However, in 1994, there was a strike by the militant NASU, who were generally feared because of their penchant for violence and use of juju to prosecute their strikes. At Wesley Guild Hospital, Ilesa, support services were shut down and the striking workers forbade the wards to be cleaned:

"I then did a very foolish thing. I drove up to Ilesa, got hold of the Unit Administrator and the Physician-in-Charge and we started cleaning the wards..." (p. 45). The striking workers got hinted about the activities and mobbed them. He was struck on the head with an 'atori', a fetish branch of shrub which was meant to make him weak and collapse (though none of these happened). He was ruffled. This would become his signature way of confronting striking workers over time i.e. tending to undermine their actions by taking over their services, and physical confrontations to ensure and enforce the continuity of withdrawn services by the striking workers.

\subsection{Industrial Crises in the University}

Countless crises ensued in the University after the initial crisis fomented by the cult attack on campus which ushered him in as Acting Vice-Chancellor. However, we shall limit ourselves to one (out of many) involving the non-teaching staff, one with ASUU (Academic Staff Union of Universities), and one with students. We shall view them in contrasting contexts.

The industrial stalemate between the Management of Obafemi Awolowo University and the non-academic staff unions i.e. NASU and SSANU was what some pundits have termed the mother of all battles in the history of industrial actions in the 
university. For one, it was a battle for legitimacy (for the pros), and a struggle of one man to de-legitimize a long-standing and an aberrant industrial culture (for the cons).To some people, the scenario that played out distinctly show that the ball inflates when it is ASUU (Academic Staff Union of Universities) and deflates when it is about other unions.

On 23 $3^{\text {rd }}$ February, 2000, SSANU (Senior Staff Association of Universities) and NASU (Non-Academic Staff Union), declared an industrial boycott on Examination Administration Allowance. This allowance was approved by the Federal Government for people involved in the administration of examinations. It became an issue when it was perceived as a booty meant exclusively for academic staff. A full-scale animosity gradually built up and exploded as other unions took up the gauntlet and interpreted this as a brazen declaration of war on them, as according to them, all staff are directly or indirectly involved in administration of examination, hence should equally benefit from the allowance. They immediately embarked on industrial action and total cessation of services.

"For years, the practice during industrial actions was to withdraw the supply of electricity and water. They would even sabotage the installations to ensure that, even if the University succeeded in bringing people in to operate them, this would not be possible. In any case, they believed that no one else could operate these systems. Needless to say, they would allow Bursary staff to come in to process salaries when due."(Pp.125-126)

The stage was set for a contest of demystification between a principal who was tasked with the responsibility of ensuring that the system worked by all means possible (as the Senate of the University pronounced that he should get them to work), and the raging non-academic unions who would stop at nothing to safeguard their deactivated services from hijack and ensure that services remained totally suspended in furtherance of their lock-out action. Armed with shotguns obviously to protect themselves from attack from striking workers, the Vice-Chancellor and his friend(s) visited the municipal offices and, with outside interference from non-staff experts, manipulated the machines and were able to pump water and provide electricity to campus, after series of face-offs.

In one of such attacks, the melee degenerated to mob attack. As mentioned earlier, this brigandage provided opportunities for inter and intrapersonal conflicts where the principal was forced to operate between Charybdis and the deep blue sea. Personal attacks were directed at him not only by the grieving unions but also by members of his constituency who had some pathological scores to settle with him in and out of Senate Chamber. On interpersonal level, he found it difficult to mitigate the scuffle as a result of his pre-emptive non-alignment with the nature of the leaders of SSANU and NASU, Messers Afolabi and Akinnubi, who he described as "thoroughly bellicose" and "malignant"(p.127). Hectored between the academic staff who insisted that the allowance should not be extended to non-academic staff, and the non-teaching staff who believed that the Vice-Chancellor being an academic staff, had taken the sides of his academic colleagues, the stage was set for forceful engagements. This was not helped by the event 
that followed after. In November 2001, the Federal Government implemented the new salary scale structure, but failed to include the $22 \%$ differential earlier agreed with ASUU. The differential, which was in respect of the salaries of academic staff vis-à-vis that of their non-academic counterparts, was expected to be calculated based on the new enhanced salary; but was calculated based on the old salary. This was rejected and ASUU went on national strike. A year earlier, during the industrial dispute embarked upon by nonacademic staff, the Vice-Chancellor had taken the proposition for 'No work, no pay' to Council and defended it. It was approved that the university should go by international standard, and that thenceforth, salaries shall not be paid for work not done. The principle was used for SSANU/NASU strike of 2000 and was enthusiastically endorsed by Management. However, the tune changed with ASUU strike of 2001. It became difficult to implement as though the principle received plaudits from the Governing Council and Senate of the University when it was first used for SSANU/NASU, it was roundly rejected and resisted, despite the persuasions of the CEO that the discontinuance at that point in time would seek to encourage irresponsible industrial actions. His attempt to canvass the support of academic staff at ASUU congress and make them see reasons why they should not be paid for work not done fell flat. Personally, the Vice-Chancellor visited notable Nigerians like Gani Fawehinmi to canvass ASUU's position on the differential, and to prevail on the Federal Government to yield grounds. This action made some nonacademic staff members uncomfortable. The strike was eventually called off and the insistence of ASUU paid off eventually when the 3-months salaries stopped as a result of the 'No work no pay' principle was paid. But this was after one year of academic activities had been lost, during which time the University remained closed. The Vice-Chancellor admitted that he was able "...to deal with NASU and SSANU effectively..." but the same cannot be said for ASUU. (p.232)

\subsection{Students' Crises in the University}

Protest and unrest gained ascendancy and notoriety from the historical antecedents of the University. It was often said that turbulence was not alien to the institution, and that the chicaneries and political maneuvers that saw to its establishment only attested to future apoplectic culture. OAU was synonymous with aluta. Successive administration had struggled to palliate and alleviate this tradition of confrontation which climaxed during Professor Roger Makanjuola's tenure. Riding on the goodwill of the ownergovernment and the traumatized students whose psyche were brutalized by the July 10, 1999 cult attack, the Acting Vice-Chancellor (and later, Vice-Chancellor) gained popularity for his populist and an anti-corruption stance. He did things differently, enshrined his triadic mantra of hard work, honesty and honour, and as he variously averred in his book, never believed in running away from students or staff. Some people may argue that while this may sound good and innocuous, he bungled it by indulging in it a bit too much, as most of his contemporaries believed that a Vice-Chancellor should maintain a dignifying distance from the students and from members of the community generally so as not to lose the respect of the community (p.179). Some even argued that 
in the civilized world, you don't get to see your Vice-Chancellor commonly except on matriculation and graduation days. In essence, while it was the practice of some ViceChancellors to sit fat on their thrones like an African bullfrog maintaining minimal contact, Roger mingled freely with the students' leadership thus, deconstructing the esteemed post.

"To be a distant deity was not my style. I felt that these were young people who had been traumatized by the 10 July incident and who had lost confidence in the University Administration." (p.180)

Despite this uncommon camaraderie crises still brewed from time to time, between students' leaders and the person of the Vice-Chancellor. Either that some took his easy accessibility as an opportunity to be rude to him in order to present a 'macho image', or that the culture of militancy for some reasons soared to an unprecedented height during this era, what is obvious is that students' gangsterism and unruly brigandage became the order of the day. Apart from the regime of Lanre Adeleke (a.k.a. Legacy) which was relatively peaceful and cordial with administration, other Student Union leaders after him had remained deviant and hostile. Through the tenure of Adeniyi Akanni Adenekan (a.k.a. 3As) to that of Yinka Sotade (a.k.a. Burkina Faso) who was removed for lack of militancy, to Akinkunmi Olawoyin (a.k.a. Revolution), Muhammed Elegbede in 2004 (a.k.a. MM) whose office was hijacked by his PRO, Mr. Olowokandi, and who was also removed for lack of sufficient militancy; and, towards the tail end of the Vice-Chancellor's tenure, Olanrewaju Idowu (a.k.a. Diamond) who also saw hell as his office was hijacked by dissident and rusticated culprits who had refused to vacate campus. In all these narratives, there is no gainsaying that the tradition of violence in Management-students' relationship reached a climax. In his genuine efforts to assert the authority of Administration and to exact commensurate punishment for crimes committed by criminally-minded students, the principal whose earlier action of advocating for the pardoning of 'the Ife Eleven' (a set of students dismissed for disrupting the 1995 convocation ceremony) was possibly misinterpreted as a blank check for condonement of indiscipline wanted to force compliance. The protests, the brigandage, the militancy, the thug culture, robbed the exalted position of the Vice-Chancellor of its dignity, and, at a point, almost claimed the life of the Vice-Chancellor:

"I was carried bodily out of the room into the corridor... At first, I thought I was going to be hurled over the corridor wall to my death seven floors below. However, they carried me along the corridor to the stairs. I struggled hard, and repeatedly grabbed hold of whatever handholds I could find... I was continually kicked and beaten. I was repeatedly floored, and would struggle to get up only to be beaten to the ground again... I was dragged across to the front of the 'Motion Ground', where a bus...was waiting... The mob shouted out that I should get into the bus, which was to take me to Awolowo hall. I refused and continued struggling."(p. 207). 
Like some people later submitted in Senate that held shortly after the incident, the symbol of authority was dragged in the mud by this action. Never had a Vice-Chancellor been bundled down from the seven-floored University Secretariat and mauled by his students in the history of the University. The saddest part was the fact that most members of staff were also complicit in the show of shame.

However, one must commend the courage and bravado of the Vice-Chancellor in all cases during these turbulences. His actions at every point in time show honesty of purpose and passion to restore sanity, and to lead a battle at all times. He was ever ready to risk his comfort and positions for his staff and students:

"On the night of $5^{\text {th }}$ July 2003, I was informed over the walkie-talkie system that a large group of students had invaded the power-house (power generating house-emphasis mine) and kidnapped a member of staff...(over power failure-emphasis mine). I drove to the scene to find an angry mob of about 100 students milling about.(The staff) had been bundled into a commercial vehicle and was about to be driven off to Awolowo Hall (for torture-emphasis mine). I had to get into the vehicle with him to prevent this from happening... While various individuals kept running in, kicking me and then running back into the crowd, I continued to insist that (the staff) would not be taken away." (p.193)

This often is the sacrifice of leadership that most of our leaders would rather not risk. Leadership entails more than savoring the big nomenclatures and perquisites of office, but strong presence and taking charge when it matters most:

"The reader may well wonder why I got into these dangerous confrontations so often. I could certainly have avoided the personal confrontations. Indeed, in most of the incidents ...I was advised to stay clear. There are a number of reasons why I did not "run away." First, I believe firmly that a VC who runs away from his students (or indeed his staff) has no business being a VC. I also must admit that I am stubborn as well as confrontational." (p.217)

Much as one may disagree with his bohemian style of administration, one cannot but agree with his principle of 'not running away' from the led. The practice in most cases in our officialdom is to create a lacuna and maintain a 'dignifying' distance. However, this had proved ineffective over time, as it encourages operational gaps and misinterpretations. Hence, one must learn how to remain 'dignifying' even in not running away.

\section{Findings}

What leaps out readily from the book is that theatres of contestation require tact and compromise at all times, especially when it involves people of age-gap generations. It is obvious in these conflicts that the contests are often interpreted in the light of 'the will to 
prevail' rather than in the genuine spirit of concord, amity and amelioration. The Marxian interpretation of conflict in economic space and the definition of it as a hustle for finite resources does not always hold in the universities, especially with regards to students. In this instance, it is more of quasi-Bolshevism, a revolution that seeks to enthrone anarchy and upturn the organogram. While it may be true that the cause of conflict with staff was as a result of a never-ending struggle for finite resources, events had shown that the expansive definition that it is 'all forms of opposition, disagreement, friction between two or more parties' (T.O. Adeyemi and S.O. Ademilua) is more apt. The reason is not necessarily economic. It may be infrastructural, political, personal or general discontent.

Reading through the book, certain things became obvious:

\section{a. Vassal Groups}

The tradition of militancy did not develop overnight, but had been long time in the making. We noted earlier that it is usually said that the tradition had been from inception. But this was an intangible declaration that could not be substantiated. What could be proved however, was the fact that the structure for students' brigandage had been laid through the permission of ideologically slanted groups like the Pacesetters and Democratic Socialist Movement who had been allowed to become too powerful over time and to enthrone and dethrone Student Union officials. They get encouragement from outside 'godfathers' who sponsor them financially and give them physical support to perpetrate all kinds of atrocities and hijack the machineries of government at the center;

\section{b. Management Training}

The need for adequate training in all forms of endeavor is germane. It could be seen that 'learning on the job' comes with its own risks, and that academic erudition does not necessarily translate to administrative adroitness. (Bakare, K.A., 2021). Much as it may be tactically correct to have an academic staff as CEO of universities, thus, having the services of someone who knows the in and out of academic practice, it is germane to have such people trained constantly for the managerial aspect of the job as they cross boundaries, rather than leaving them to learn on the job;

\section{c. Coffee Room Brutalities}

This is a room in Awolowo Hall that was reserved for torture of apprehended 'culprits' and sometimes, people who were averse to the popular position of the Student Union. Though it is no longer in existence, it was allowed to exist for a long time despite that the nefarious activities perpetrated within were not unknown to the university authority. In recent past, it ended up hosting a Deputy Vice-Chancellor, a Registrar, and other perceived enemies of the Union. It is unfortunate that during the tenure in question, three young people ended up losing their lives owing to 'coffee room treatment';

\section{d. Student Union Government}

The Students' Union of Obafemi Awolowo University was the aluta flagship of the studentry and remained the rallying point of aluta evangelization. However, during the tenure in question, it became so powerful that it aimed to set up a parallel government. The students defer to the Union more than the central authority, and took the directives issued by this body more seriously. The unguarded zeal of its leaders at the time in 
question took the better of them as they strove to entrench violence and dissension against the central authority as means of gaining popularity and legitimacy. They perceived discontent even where there was none, and tended towards a complete takeover;

\section{e. No Work, No Pay}

The 'No work, no pay' brouhaha that played out during the Vice-Chancellor's encounters with staff unions leaves a sour taste in the mouth. The writer admitted that this is one of the lowest points of his administration, as he effortlessly enforced the principle on the non-academic staff, but was unable to enforce same on ASUU. The impression that he pandered to his academic constituency would forever remain with the non-teaching staff as he was not able to convince them that he was an independent umpire. He asseverated his unmitigated belief in the principle, as obtained in the developed world, but he soon learnt that: "While other universities were discreetly paying the salaries of their staff, we were holding rigidly to the Government's position" (p.231). The other Vice-Chancellors had adopted 'native intelligence' to solve a humongous problem, while he remained unbending;

\section{f. Taking Over Services of the Non-Teaching Staff During Strikes}

The Vice-Chancellor severally 'dealt' with the non-teaching staff during their strikes by 'poaching' their services and thus rendering the strikes ineffective. This caused a lot of problems as the striking workers tried to prevent the hijack of their functions, which by implication, would render them irrelevant. In Sections 2.2. (b \& c) and 2.3 of the Nigerian Labour Law, the rights of trade unions to 'embark on an industrial strike action; and engage in peaceful picketing ' were guaranteed. The Trade Union Act also prohibits trade unions from:

...carrying out a strike or lock-out, or engaging in any conduct on contemplation or furtherance of a strike or lock-out, unless:

(b) the strike or lock-out is in relation to a labour dispute that constitutes a dispute of right;

(c) the strike or lock-out concerns a dispute arising from a collective and fundamental breach of contract of employment or collective agreement on the part of an employee, the trade union or an employer;

(e) a simple majority of all registered members voted to go on strike"

The Trade Union Act 2004 (as amended) which governs the activities of trade unions in Nigeria is not in support of such acts that might serve as an existential threat to the means of sustenance of such workers, especially, when similar act could not be visited on the teaching staff by the government or the local authority. Imagine taking the services of striking lecturers by employing foreigners or other teachers to take up their spaces. If done, it would be roundly condemned. The Vice-Chancellor's penchant for open confrontations with striking workers and his intrepid Cowboyish recklessness was often described by the cons, as demeaning and compromising his image as the primal symbol of the University. 


\section{g. Effect of Incessant Strikes}

Conflict in Nigerian universities had more often than not, blustered into violence. Destructive behaviours and incessant cessation of services had resulted to compromised standards, cancelled sessions, abbreviated calendars, stress and battered international image. A strike-stricken academia is a rickety system prone to collapse. Each new strike marks a step towards extinction of standards, as constricted calendars always ensured that students lose more than they ought to gain. Unfortunately, the system is helpless when it appears as though, strike is the only language the owner-government understands, as they had always waited for commencement of strikes to galvanize them to action, and to re-negotiate unhonored agreements that were freely signed in the first place. With every strike, standard is incinerated, lives are damaged, and ethics are thrown out of the windows:

"When lecturers go on strike, students don't get taught... When doctors go on strike, people die and there is untold suffering because death is irreversible." (p.43)

\section{h. Astute Responsibility}

Fine statesmanship and a great sense of responsibility was exhibited by the ViceChancellor in these trying times. It is clear from the events recorded that he was a man with honest intentions for the institution, though a few numbers of them got thwarted by the prevailing circumstances, inexperience and pellucid nature. He was always ready to stand up and take charge even when it was least advisable and dangerous to do so. He would take action, bear the consequences and accept guilt whenever it became obvious that he goofed. Though he admitted that he could be pathologically stubborn, what stood out for him was his swashbuckling temperament to confront situations and challenges the best that he could.

\section{Recommendations}

Max Weber believed that social conflict and social change could result from discourse and exchange of ideas. Extending the frontiers of revolutionary actions to dialogue and compromise had served the theory in good stead and had bestowed upon it the needed multiplicity of approach. The contestations in the book were not merely about a share of resources but also about power wrestling due to clashes of interest. It is not just about organizational rewards, but, about power tussle and mob culture. There are four ways of dealing with conflicts; through fight, negotiation, problem solving, or through design (De Bono, 1985). The conflicts in the book were mostly tackled using the first option. Some people may argue that the option was adopted only after the failure of dialogue, but it is yet to be seen whether there is any viable alternative to dialogue. Deconfliction, forceful annihilation of conflict, precluded negotiation or bargaining. It is replete with innuendos, especially when it is about battling for the soul of the system. Oftentimes, forceful deconfliction leads to death and the expression of angst and regrets. These maelstroms, 
these gale of protests and violence, these combustions, these bullfights could be put in check through effective dialogue. Conflicts in Nigerian universities are like growing monsters (Adeyemi and Ademilua, 2012), and managing it requires participative and democratic style for effective administration. When you are dealing with people, you are not just dealing with raw commands and arithmetic sequence. You are dealing with emotions, values, ethos, hence the need to balance the equation. The paramountcy of diplomacy and dialogue cannot be controverted in this respect.

\section{Conclusion}

We have been able to show the hydra-headed crises and crises management revealed in the exploratory account of Professor Roger Makanjuola as the former Chief Medical Director of a Teaching Hospital, and Vice-Chancellor of a foremost university in Nigeria. The conflicts, which ranged from human, communal, religious and other macro, meso and micro conflicts show the burden of leadership, and the challenges faced in antagonistic terrains. We have particularly zeroed down on the industrial conflicts with a view to highlighting the management of crises and the difficulties encountered in so doing. The treatise, a masterpiece on how to manage, and how not to manage conflicts in large organizations, is representative of the challenges of management of HEIs in Nigeria. Its fluid style and self-scoring assessments make it a transparent rendition and a compendium on how to move management discourse forward.

\section{Conflict of Interest Statement}

The authors declare no conflicts of interests.

\section{About the Author}

Mr. Kamal Adetunji Bakare is an astute professional with over twenty years' experience in the field of University Administration in Obafemi Awolowo University, Ile-Ife, Nigeria. He served in many units in the Registry of the University and had performed creditably well as Head of the units. He is also a student of Literature, and a connoisseur of knowledge. He has contributed articles published in Global Journal of Human Resource Management, Global Journal of Political Science and Administration, British Journal of Education, European Journal of Human Resource Management Studies, European Journal of Management and Marketing Studies, and Asian Journal of Social Science and Management Technology respectively.

\section{References}

Adebayo, P. F. (2007). Student Crises: The dimension of Student-Police relation in Nigeria. Ilorin Journal of Education. 21(1), p.75-84. 
Adepoju Adeleke (2001). Management Concepts and Applications. Concepts Publication Limited, Lagos, Nigeria.

Adeyemi, T. O. and Ademilua, S. O. (2012). 'Conflict Management Strategies and administrative effectiveness in Nigerian universities.' Journal of Emerging in Educational Research and Policy Studies; 3 (3): 368-375. Retrieved from https://citeseerx.ist.psu.edu/viewdoc/download?doi=10.1.1.301.744\&rep=rep1\&ty pe=pdf

Bakare, K. A. (2019). University Administrators as Endangered Species: The Nigeria's Situation, a paper published in Global Journal of Human Resource Management, by European- American Journals, ECRTD- UK, Print ISSN: 2053-5686. Vol. 7, Issue 4, September 2019, online ISSN: 2053-5694 (Online), https://doi.org/10.37745/gjhrm.2013.

Bakare, K. A. (2021). Unions, Government and the University Enterprise in Nigeria. A paper published in the British Journal of Education, by European-American journals, ECRTD-UK, Print ISSN: 2054-6351. Vol.9, Issue 3, pp.106-119, 2021 (Print), Online ISSN: 2054-636X (Online), https://doi.org/10.37745/bje.2013.

Bloisi, W. (2007). An introduction to Human Resource Management. McGraw-Hill, London. Edward de Bono (2018 reprint). Conflicts: A Better Way to Resolve Them. Ebury Publishing. www.books.google.com. Accessed April 21, 2021.

Fatile, J. O. and Adejuwon, K. D. (2011). 'Conflict and Conflict Management in Tertiary Institutions: The case of Nigerian Universities.' Published by the European Journal of Humanities and Social Sciences, Vol. 7, No. 1 (Special issue).

Ibukun, W.O. (1997). Educational Management theory and practice. Bamgboye and Co., AdoEkiti.

Jacob Bercovitch and Richard Jackson (2009). Conflict Resolution in the Twenty-first Century: Principles, Methods, and Approaches. University of Michigan Press.

Karl Marx (compiled 1964). The Civil War in France. People's Publishing House, Peking, People's Republic of China.

Karl Marx and Conflict. www.books.google.com. Accessed April 20, 2021. McGraw-Hill, London.

N. Kirchoff and J. R. Adams (1982). Conflict Management for Project Managers. Drexel Hill Project Institute.

Nigeria: Employment and Labour Laws and Regulations 2021. https://iclg.com/practiceareas/employment-and-labour-laws-and-regulations/nigeria. Retrieved April 23, 2021.

Olaleye, F. and Arogundade, B. (2013). Conflicts Management Strategies Organizational Psychology.

Posigha, B. E. and Oghuvwu, V. (2009). Conflict among Library Staff in Bayelsa and Delta State of Nigeria. International Journal of Labour and Organizational Psychology;

Roger Makanjuola (2012). Water Must Flow Uphill-Adventures in University Administration. Mosuro Publishers, Ibadan, Nigeria.

Socialization. https://www.sociology.com. Accessed April 21, 2021. 
K. A. Bakare

CONFLICT AND CONFLICT MANAGEMENT IN NIGERIAN UNIVERSITIES: A STUDY OF

ROGER MAKANJUOLA'S ‘WATER MUST FLOW UPHILL: ADVENTURES IN UNIVERSITY ADMINISTRATION’

Tunde Monehin (2016). Introduction to Management. KULO Printers, Akure, Nigeria.

Creative Commons licensing terms

Author(s) will retain the copyright of their published articles agreeing that a Creative Commons Attribution 4.0 International License (CC BY 4.0) terms will be applied to their work. Under the terms of this license, no permission is required from the author(s) or publisher for members of the community to copy, distribute, transmit or adapt the article content, providing a proper, prominent and unambiguous attribution to the authors in a manner that makes clear that the materials are being reused under permission of a Creative Commons License. Views, opinions and conclusions expressed in this research article are views, opinions and conclusions of the author(s). Open Access Publishing Group and European Journal of Education Studies shall not be responsible or answerable for any loss, damage or liability caused in relation to/arising out of conflicts of interest, copyright violations and inappropriate or inaccurate use of any kind content related or integrated into the research work. All the published works are meeting the Open Access Publishing requirements and can be freely accessed, shared, modified, distributed and used in educational, commercial and non-commercial purposes under a Creative Commons Attribution 4.0 International License (CC BY 4.0). 